\title{
Is There Any Risk of Second Wave of Crises?
}

\author{
C. YILMAZ, A. ELEREN, B. İLTER \\ Afyonkocatepe University, Afyon, Turkey
}

\begin{abstract}
Globalization and the world trade agreement affected the equations in the world trade and disrupted the existing trade balances severally. Consequently, the nature of trade environment has changed. Potential failures and risks: deficiencies in banking systems, huge budget deficits, lack of positive investment clime (abnormal LİBOR and Central bank rates), are still exist in the international financial market place. Additionally, market makers and regulators are neglecting the basic financial rules to solve the problem. They were mostly concentrated on lower interest rates and provided cheap finance to the financial sector, which was easing the market conditions but not repairing the conditions in the long term which caused hidden trade wars and interest wars. Extraordinary low rates interest rates results in extraordinary low currency values. However, global trade needs at least one strong reliable currency. In the past, it was US dollars but not now. Decision makers have to gather correct and reliable information to take decisions, but accounting scandals, rating, and accounting firms' controversial and mostly late reports indicate that there are serious doubts about them. During the crises, decision makers, politicians and central banks, pumped liquidation to the markets can be considered as painkilling solution for the financial markets. These solutions have not provided serious progress until now. This study suggests tough and possibly efficient but difficult solutions, like unilateral agreements on international trade and economics, setting of a guaranteed information system, harmonization of accounting and financial reporting standards which would be more appropriate, otherwise, potential new waves of crises are inevitable.
\end{abstract}

Keywords: global crises, abnormalities, trade wars, reasons of crises, deficiencies in banking systems, negligence of basic rules

\section{Introduction}

Within today's global business environment, the concept of risk is hugely widened from simple marketing issues to very complex financial matters. Very complex global business environment makes it necessary to make more accurate predictions. Without accurate predictions, healthy businesses management or governance is almost impossible. But all the predictions consist of a margin of errors. The term, risk can simply be defined as "possibility of unpleasant results that might occur because of unexpected futuristic events". Here the fact is that no one can predict any event with a hundred percent certainty, i.e., every futuristic decision or happening consists of certain amount of uncertainties and risks. Hence, it could be predicted that there is certainly a risk of second wave of global crises (even the third and the fourth wave).

C. YILMAZ, Assistant Professor, Doctor, Business administration, Afyonkocatepe University.

A. ELEREN, Associated Professor, Doctor, Business administration, Afyonkocatepe University.

B. İLTER, Assistant Professor, Doctor, Business administration, Afyonkocatepe University.

Correspondence concerning this article should be addressed to C. YILMAZ, A.K.Ü., İ.İ.B.F., ANS kampusu, egitim-3, Afyon/Turkey. E-mail: ylmzcc@yahoo.com. 
However, the crucial aspects are with the risks: if the degree of risk is big enough to take into consideration to take precautions or not? And if the level of the damages is big enough take precautions? Obviously, if the chance of materialization is too low (let's say a million to one), it can be ignored. Similarly, if the degree of possible damage is low and the cost of taking precaution is too high, it might not be logical to take precaution.

First wave of the global crises has already damaged the world economy harshly, and the possible second wave would be more harmful. Majority of the governments have already used their financial weapons and ammunitions in the first battle, like low interest rates, pumping excess liquidation to the market, and have provided budget deficits to stimulate the markets. In the event of second wave of crises, markets would not be sensitive to such measures or they might gain immunity to such measures which would make the markets more depressive. Indeed, there is no or very limited space for such measures at present. For example, interest rates are already around or below one percent.

On the other hand, there are serious disputes amongst the academicians and policy makers about "if the global crises would strike the world economy again? Or not?” or "are there serious treats for the second strike?” which are also the main queries that will be elucidated in this study. This study is trying to examine the risk factors which are thought to be the sources of global crises, if they are eliminated? Or otherwise, do they still exist as potential threats for the second strike?

\section{Literature Review}

In 1996, chairman of Federal Reserve Alan Greenspan warned against "irrational exuberance” in stock markets. Indeed, it was not the only irrational exuberance (or overvaluation) taking place in stock market, there were other markets, like money markets, housing markets, commodity markets etc., which were irrationally exuberance.

On September 2007, Nouriel Roubini, the man called as Mr. Doom, warned the International Monetary Fund economists that the crises were brewing, and that the United States would be faced with housing bust, declining consumer confidence and consequently a deep recession (Mihm, 2008). After his studies about the crises in Mexico in 1994, in Asia including Thailand, Indonesia, and Korea in 1997, and in Brazil and Russia in 1998, he indicated that their common weakness was their higher deficits which were mostly financed by excessive borrowings that were used as reckless expenditures. So their economies became more vulnerable for the crises. In addition to this, poorly regulated banking system and weak corporate governance were their weaknesses. Roubini mainly concentrated on currency deficits, lack of regulations in banking systems, and price bobbles, while explaining or predicting crises.

Some of the academicians criticized him as too pessimistic and lucky to have one lucky prediction. However, more serious critics indicated that his predications did not rely on data and mathematical models. However, his prediction about the global crises came into reality. This may be because of the lack of healthy information in the markets. Sometimes, it would be better not to use information, if the information is unhealthy for analyzing.

Just before the global crises, in a conference, Yılmaz, Elitaş, and Erkan, (2009) claimed that information related deficiencies in the global markets would cause a global crisis. They also listed some other reasons for potential global crises and tried to exhibit the similarities between the potential crisis (today it is existing crisis) and accounting scandals (see Table 1). 
Table 1

Similarities Between the Accounting Scandals and Expected Global Crisis

\begin{tabular}{|l|l|l|}
\hline & Accounting scandals & Expected global crisis \\
\hline $\begin{array}{l}\text { Information related } \\
\text { deficiencies }\end{array}$ & $\begin{array}{l}\text { Lack of credible accounting and financial } \\
\text { information of related firms. }\end{array}$ & $\begin{array}{l}\text { Lack of monetary information provided by the central } \\
\text { banks: uncertainties on emission, provisions etc.. }\end{array}$ \\
\hline $\begin{array}{l}\text { Abnormal assurances from } \\
\text { authorities }\end{array}$ & $\begin{array}{l}\text { Abnormal assurances to enforce public } \\
\text { confidence about their firms (ex: ken lays } \\
\text { speech before the collapse). }\end{array}$ & $\begin{array}{l}\text { Several speeches by presidents, prime ministers and } \\
\text { central bank authorities etc.. }\end{array}$ \\
\hline Negligence of basic rules & Asset pricing, fundamental analyses etc. & $\begin{array}{l}\text { Bretton-Woods model, Purchasing power parity, fisher } \\
\text { effect, international fisher effect etc.. }\end{array}$ \\
\hline Value traps; bobbles & High share prices & High currency values \\
\hline
\end{tabular}

Note. Source: Y1lmaz et al. (2009, p. 153).

In this study, they tried to analyze the general attitudes and positions of some professions (such as chief officers, accountants, auditors, brokers, and analysts etc.) in terms of health of information provided to the markets. In comparison to Roubini's reasons, they suggested that information related deficiencies, negligence of the basic rules and the bobbles in international markets were the main reasons for the expected global crisis. Abnormal assurances of the authorities are considered as an indicator or warning for the crises. Before the crises, they suggested that globalization, WTO agreement, and inappropriate financial reporting systems (and fraudulent activities in accounting practices) seriously destructed the perfect market conditions which were resulting with misevaluations (mostly overvalued prices). Additionally, they suggested structural deficiencies and the attitudes of several professions to support overvalued markets which also increased the risks in the global financial markets. Reinhart and Rogoff (2008) indicated that there was an association between the recessions and overvalued prices. Claessens, Kose, and Terrones' (2008) study also indicated that there was a correlation between the recessions and the credit crunches which resulted in busts in the equity markets. Besides Mishkin (1991) addressed the role of asymmetric information in financial crises well before the crises. In parallel to Mishkin, Y1lmaz (2009) suggested that the disinformation activities (as one of the reason for global crises) became a fashion or core competency in today's financial markets, and listed five types of disinformation activities in financial marketplace.

In the literature, there were several other possible reasons for the crises, for example, Eichengreen and Rose (2001) claimed that the main sources of banking crises were: low GDP growth rates, inappropriate interest rates in particular country and interest rate increases in international financial markets etc.. However, in some cases, large traders operating currency markets were blamed to create panics or to make manipulations in the market place like Soros. Patricia (2009) studied the reasons why the accounting bodies and researchers had been unable to predict the crises and gave two reasons for the failure: firstly, the gap between the academic accountants and the accountants in practice; and secondly, the failure to understand and adapt the economical and political environment in which the accountants operate. In the theory, it is believed that those markets and their actors act rationally.

Several studies indicated that there were usually two main reasons for the crises, related to each other, which were mostly called as twin crises. This study indirectly indicates that one reason or problem triggers or reinforces the other one, and the problem or the crisis becomes intolerable and its bad results come into reality. Shin (2005) suggested that attacks on currencies and the crises in the banking system resulted in the Asian financial crises. Allen and Gale (2000) indicated that bubbles in asset prices affected the banking system and resulted in the crises. Buch and Heinrich claimed that banks played an intermediary role in twin crises. 
Kaminsky and Reinhart (1999) argued the causes of banking and the balance of payments problems in twin crises. Dreher, Herz, and Karb (2006) examined the linkage between the currency and debt crises. These and other studies clearly indicate that there are usually multiple reasons for the crises rather two reasons. So, it can be called "collective crises" rather than twin crises. Because there are numerous risks existing in the marketplace, when one becomes real, it triggers the others. The result is a crisis.

\section{Assessment of Possible Failures and Risks That Caused the Crisis}

As could be viewed in the literature, there are multiple possible reasons for the global crisis, which mainly default in banking systems, budget deficits, imperfect market conditions, deficiencies in accounting systems, disinformation activities in international financial markets etc.. To make an appropriate assessment for the second wave of the crises, academicians and the policy makers have to re-assess these factors, whether these factors have been eliminated or not?

\section{Deficiencies in US Banking System and High Budget Deficit}

Whether like it or not, the US is the leading actor in international trade and in international financial system, and the US currency (dollar) was (and is) the main reserve currency in the globe. In consequence, any serious development in the value of the US dollar could seriously affect the trade in the world and the global financial system.

Accounting scandals and the misinformation or disinformation activities just before the global crisis clearly indicated that US banking system had deficiencies in evaluating risk, and US accounting system failed to warn the markets about such risks. After the accounting scandals, US government has taken serious and tough measures, specifically Act of SOX, but it also failed to activate the accounting system for warning crisis. Nowadays, series of new legislations are put into practice and the new legislations are on the way.

There are several critiques about them, for example, market players indicate that these legislations would restrict the creativity of financial actors where creativity could be considered as a core competence in NYSE. On the other hand, some others would suggest that these legislations still do not ensure the healthy information flow which is essential for market efficiency. When the markets efficiency goes down, the probability of crisis might increase.

In this context, there is no any new regulation that would provide the independence of auditing mechanism. Internal and independent auditors are still dependent on their clients' fees. There is no any auditing guarantee system that would secure the health of the information. It is believed that the existing regulative restrictions in banking system should have been adapted to the regulation of the auditing system in the US. However, the actual result would be interpreted within time. Besides, the global crisis took place all over the world, so the precaution should have been taken globally. Except the US, the other governments were reluctant to take further internationally harmonious actions for the banking and accounting systems.

In the literature, several studies indicate that one of the major sources of crises is the budget deficit. Before the global crises, US budget deficit reached to record levels and the crises came into existence in the US. However, a general thought about the solution by the policy makers is pumping up more liquidation to the markets and increasing the deficit. This is a contradiction, if the deficits are the reason for crises, the main therapy cannot be "creating more and more deficit". It is believed that pumping liquidation to the markets would be temporary solution to ease the pain, like using a painkiller that does not cure the main illness.

Majority of the central banks followed the US central bank policies and pumped up huge amounts of 
liquidation to the market. This liquidation was mostly directed to unproductive areas like infrastructure investments. Such investments generally do not generate return (at least in the short term). Even if there is a return or benefit, it could be generated in a long period. Moreover, a study prepared by the IMF member (seen in the press) claimed that governments had to increase their deficits by making more expenditure to eliminate the effects of crises. The US budget for the 2010 passed from the Senate House with the record deficit. So, it can be suggested that the budget deficit problem in the US, still remains as a serious risk for the second wave itself. Another side effect of the budget deficit is the unpreventable high inflation which is mostly ignored by the policy makers.

The liquidation injected by the central banks are absorbed by the investors who used to be more active in the past but became passive (less active) for the moment.

But, after the crises, they prefer to stay away from investing in risky real sector since lower earning margins in comparison to high risks they might take. That is why resources used for active investments have moved and are moving through the passive investments like gold, commodities, and real state since the lack of positive investment climate. If this attitude has been strengthened in the investment community, a risk of high inflation would be unavoidable.

Furthermore, lack of active investments is causing unemployment in the world and the purchasing power of the population is going down. Additionally, confidences to the economies are still low which makes the customers to stay away from purchases. These are the signs of stagnation, and may be stagflation which can be considered as combination of stagnation and inflation.

\section{Lack of Positive Investment Climate}

Theoretically, in the free market conditions, there are three main parties which actively play crucial roles in investment activities: investors (fund providers), the entrepreneurs (fund users), and banks (bankers) between them as intermediaries. Theoretically, only at the optimum level, the interest rate could provide a balance in between the investors and entrepreneurs at which point there would be optimum level of investment. Level of interest rates should not be too high, willingness of the entrepreneurs would be too low. On the contrary, it should not be too low, willingness of the invertors would be too low (see Figure 1).

However, today's interest rates (mainly shaped by the central banks) change around 1\% which is more below than the optimum levels. This obviously stimulates the entrepreneurs' risk appetite, they can recklessly take risks (a possible reason for the global crisis). On the contrary, this level of interest rate critically limits the willingness of savers to invest in productive investment (see Figure 2), they prefer to invest in less productive (non-job creating) investment instrument like gold.

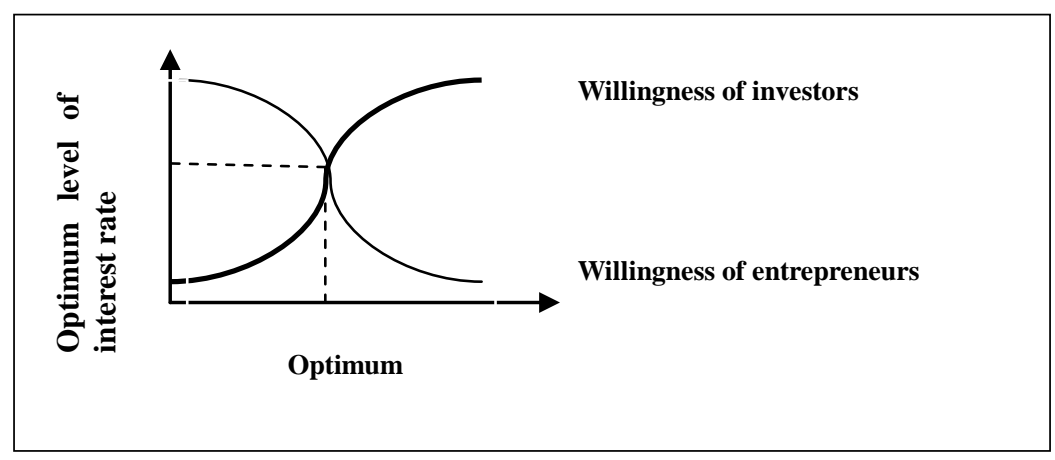

Figure 1. Ideal levels. 


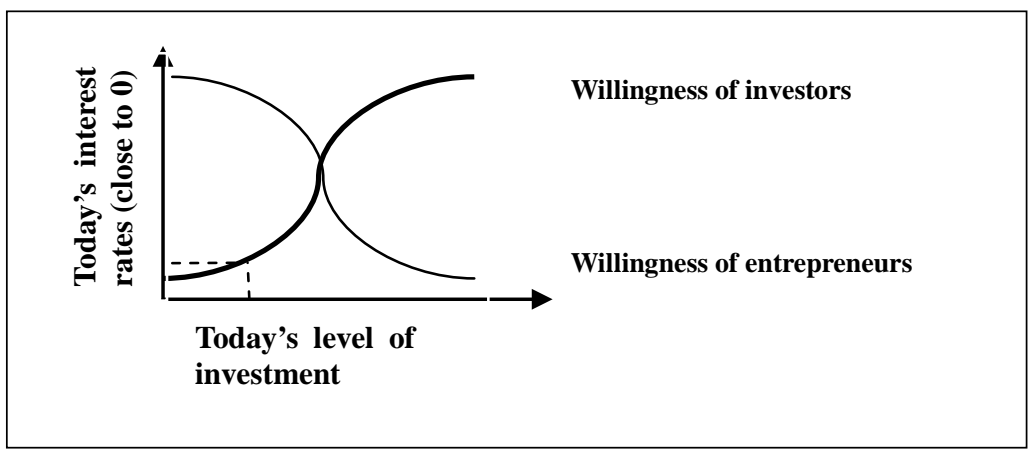

Figure 2. Today's rates.

In the theory, expected returns are the function of risk free rate of return, and the risk premiums are related to investment. Risk free rate of return theoretically should be a little bit above the inflation rate. Besides, there should be positive relation between risks and returns.

Nowadays, basic rates, used in determining the expected returns and mainly determined by central banks, are too low and mostly vary between zero percent to one percent, which is also directly or indirectly affects the market rates, like LIBOR. Basic rates are also used as an indicator for other markets and used to reduce the expected returns in the markets which are seriously reducing the confidence to the markets and reducing the willingness of the investors to invest. Besides, zero percent interest rate policies clearly defects the balance between the risks and returns. This climate is created by the main central banks' policies purposely to ease the bad effect of the crises. Here the risk is that if these policies' side effects would be more than expected?

Other aspect with investment climate is that, overly excited investment appetite in the globe and the technological developments increased the production capacities in several sectors. While there was a huge increase in production capacity demand in certain sectors critically shrank, for instance, in automobile, mobile phone, and computer sectors etc.. In such sectors, it is very difficult to create an extra demand. New demands would be created by issuing new products and services. But the private investors would be hesitant to invest in research and development activities in such risky climate that might very limited returns.

That is why one might suggest global crises which would be an opportunity to invest in research and development activities for the governments instead of investing in unproductive sectors. Possible new products and services would generate cash, value-adds, and employment opportunities for the economy where existing policies would not do so.

Moreover, in spite of today's general policies supporting and saving existing companies, supporting new entrepreneurial activities would be another suggestion. Obviously, this is an extreme suggestion in the crises environment, but maybe this crisis is an opportunity for renewing unproductive and inefficient companies.

\section{Negligence of Basic Rules}

In addition to negligence in basic rules related to interest rates and investment condition, which mentioned above, just before the crises, Y1lmaz (2009) indicated that there were some other economical rules ignored by the currency market players, such as Purchasing Power Parity, Fisher Effect, International Fisher effect etc.. The most striking sample would be the US dollars again. US dollars have not lost value as much as it have to, and time to time gained value, in spite of low interest rate policy, harsh crises in the US, pumping too much liquidation to the markets, record foreign deficit and budget deficit. Even after Obama administration's declaration of record budget deficit, markets positively reacted to the news and US dollars gained value. This 
can be interpreted as "markets gave a strong credit to US administration or to the US economy by neglecting basic rules". In a way, this behavior can be considered as a good indicator. Optimistic expectations would strengthen the spirit in the markets. On the other hand, every organism or creature has its own nature and basic instincts. In the market place, these instincts are named as basic rules. Mankind could be able to influence and change these instincts up to a degree, for instance, wild dogs could be trained and domesticated. But in some cases, underestimating or neglecting of dogs' instincts could result in disasters. Today, highly strong and influential central banks are trying to train and domesticate the markets by ignoring basic rules. Obviously, they can achieve this target, but it is also clear that there is a risk of failure of their policies as well.

Bretton-woods model which is designed to stabilize the monetary system has been enforced by several nations for years even though there were some interruptions. Within the time, other countries (accept the US) back down from the agreement. US government unofficially continued to implement the monetary policies drown in Bretton and Woods until the last decade. Therefore, US dollars became a prime or reserve currency in the world for years and years. But the burden of war in Iraq and Afghanistan, and trade deficit against to China put the US budget into trouble and they wanted to or they had to walk away from the principles. Today, no government is officially or unofficially implementing the model. But one suggests that there is a strong need for unanimous agreement on economical principles, among the nations to stabilize the markets and to provide confidence to the markets. Lack of such common agreement about the stability of currency can be considered as a threat in the currency markets that might be a reason for the second wave of crisis.

\section{Need of Strong and Reliable Reserve Currency in the Globe}

Majority of the economical decisions are related to money and its valuation. Any miscalculation would result in losses, bankruptcies or even with crises. For accurate economic decisions, there is a need for reliable calculation unit: a reliable currency. For decades, US dollars had been considered as a reliable or namely reserve currency in the world, since they used to have enough provisions assets, balanced balance sheets, innovative, and productive economy etc.. According to sayings, two thirds of the US dollar is traded outside of the US and more than half the world trade is executed in terms of US dollars. So, the role of US dollars can be considered as the mainmast of the ship that gives direction to the ship and provides energy for its movement.

Nevertheless, today's US dollars are losing value sneakingly, the mainmast of the ship is decaying, because of wars in Iraq and Afghanistan, trade deficit against to China, structural problems in the economy. Crew members (other governments) of the ship are trying to enforce the mainmast to keep the ship's direction in the line and to keep the ship in balance by keeping dollars in their reserves at the expense of making losses. If the mainmast (dollar) collapses, the ship (the world trade) might be destroyed or even sunk. For this reason, China, Japan, Arabic countries, and European countries etc. are (willingly or unwillingly) keeping huge amounts of US dollars as reserve by knowing that they will almost certainly make loss out of them. Here the main question or risk is "how long they could tolerate this situation?”. If their patience runs out, there could be panic that could trigger the potential risks as well.

Here another question arises, is there any substitute reserve currency against to US? The answer would be simply no. Because potential substitute reserve currencies and their economies are having additional difficulties. For instance, Euro is having serious problems by itself, crises in Greece and potential problems in Portugal, Spain, Italy, and France weaken the possibility. Besides, structural problems within the union: lack of swift decision-making mechanism; lack of harmony in between the countries; lack of enough provisions seriously 
weakens the euro's chance. British pound has serious problems similar to US dollars. Japanese economy has been in the recession for several years. Canadian and Australian dollars might seem to look like possible candidates, but these countries' political and economical roles in the world are restricted and their potential provisions are too small for the global trade.

There is only one currency which remains as a potential reserve currency i.e. Chinese Yuan with strong reserves, huge capacity for production and a huge market. However, there are serious doubts about Chinese currency as well: firstly, is the changing economical system in china would be adapted to the world's capitalist system in the long term? Secondly, are the Chinese policy makers have enough experience and knowledge to manage a reserve currency? The main core competency of China is the lower labor costs: is this sustainable in the long term? Or the other question: how long will the other countries tolerate China's competitive advantage-lower labor costs? Because of these advantages, China is having huge budget surpluses and employment opportunities, while the other nations (mostly the USA) are suffering from the budget deficits and unemployment. This would create or have already created a conflict of interest between the China and USA which could create a trade war against China that might include direct or indirect trade restrictions. Such possible restrictions would reduce the chance of Yuan for the reserve currency. Consequently, it might be suggested that there is no concrete reliable and strong currency in replace to US dollars.

\section{Lack of Healthy Financial Information}

Perfect market theory indicates that credible information should be provided to all market players timely and market player should have enough technical capabilities to analyze them, so that market players could make accurate analysis for pricing. Possible failures in decision-making, especially in pricing, would result in losses, bankruptcies, or even crises. Besides, providing one hundred percent correct the information is almost impossible, because the process of information generation is too long and complicated. The nature free market economy can tolerate or absorb single and minor failures but cannot tolerate major failures and mostly results with crisis.

There are several fundamental problems in relation to health of information: fraudulent activities, uncertainty, over reliance on past experiences, actions by irrational analysis. Even all the information provide accurate and suitable for usage, and all the market actors act properly, there are still possibilities of market failures (Minsky, 1992). Grossman and Stinglitz (1980) suggested that it was impossible to provide fully efficient market in terms of health of information. In his study, Arthur (2000) indicated that market players did not act rationally.

Several incidents mainly accounting scandals in the US, global crises in the world and crises in Greece clearly indicated that there were serious defaults in the health of information provided to financial markets. In some cases, these are generated intentionally (accounting scandals), in some other cases, the problem was mostly related to the systems. Auditing mechanisms which were designed to prevent and provide early warning systems for such failures failed to warn and prevent the related parties from the crises. Even Act of SOX in the US, which supposedly regulated and made the auditing system more efficient, could not make the auditors and analysts to warn and prevent the markets from the crises. There are many reasons which could be listed why they failed, briefly, they still depended on their clients (fee), not on the information users, loopholes in the regulations in financial reporting standards, lack of securitization mechanism in auditing and financial advisory system etc.. Such structural problems have not been solved yet, so in the future, such organizations would again 
fail to warn and protect the potential problems.

\section{Unemployment}

After globalization and WTO agreement, the majority of the employment opportunities moved towards East Asian countries, mainly to China, because of their cheap labor force. This movement enlarged the unemployment problem in western countries especially in USA. Besides, it limited the workers bargaining power in such countries. Therefore, the wages of the workers in traditionally exporting countries went down. Consequently, their purchasing power critically reduced which also critically reduced the purchasing powers of them and confidence to the markets. Governments have invested and are investing huge amounts of money to several projects (mainly infrastructure) to reduce unemployment. Obviously, such temporary projects might ease the affects of crises, but those unproductive solutions in short terms may not give the expected results, indeed, they might deepen the crises, with extra burden to the budgets. Besides, it is very difficult or impossible to provide a reverse labor movement in labor markets, let's say from China to the USA, at least within the short time period. Unemployment in the globe can cause serious social and economical problems.

\section{Potential Trade Wars}

After the abolishment of trade barriers with the WTO agreement, China could be able to increase its exportation which resulted in huge budget surpluses, mainly because of the advantage of cheap labor force. On the other hand, abolishment caused serious budget problems initially in the US and lately in Greece, and the potential candidates are: Spain, Italy, Portuguese, Franc, and others, which are on the list. They are all having budget deficits specifically against to China. Budget deficits are mostly considered as the basic source of crises. Several governments tried a number of policies (low interest rate, lower currency value policy, and some hidden barriers to Chinese goods) to reduce their budget deficit.

These policies can be considered as secret weapons used in the hidden trade war and against to China. But existing budget results clearly indicates that they could not succeed. They could only reduce the deficits and ease the crises. Unbalanced trade between China and other nations cannot be maintained for a long time that might be a reason for the second wave. Besides, to compete with low valued Yuan, other nations have to lower their own currency values which created a concealed undervalued currency war that destructs the nature of trade and reduces the confidence to financial markets. Such trade environment obviously is a risk factor for the second wave of crisis.

Parties, especially China and the US, are trying to keep away from such complicated and difficult problems. They are trying to keep the existing balance that is actually an unbalanced balance. But it seems that the dispute is inevitable, because of the trade deficits, war on interest rates, abnormalities in currency valuations, in risk assessments threatening almost every economy, and each government sooner or later would have to respond to them. Potential response would result in trade wars, possibly suspension of WTO agreement, hidden barriers (may be already exists), visible barriers to international trade, and more retaliations to existing monetary policies etc.

\section{Proposition for Existing and Potential Crises}

There is an agreement about two reasons of crisis: "budget deficits" and "deficiencies in banking systems”. In addition to these, it is suggested that "freeing of international trade by WTO agreement without monetary bases”, “intentional and unintentional disinformation activities in the financial arena”, and "markets' and 
central banks' ignorance of basic rules (PPP, fisher effect) were some other potential reasons for crisis. The crisis was global, consequently, the solution should be global too. Local and unsynchronized solutions would be inadequate for the global crisis and can influence limited areas.

A unilateral agreement with the WTO members (specifically between US and China), which regulates the trade issues, would balance budget indifferences up to a degree. Monetary issues could be regulated by a similar agreement that could be named Bretton-Woods the Second (or anything else) that would regulate such issues like interest rates or undervalued currencies on the basis of basic rules. To reach an agreement in such issues would be very difficult, because it might require further arrangements in price levels, salaries, working conditions etc.. Especially China and some other East Asian countries would oppose and would have difficulties in adopting such an agreement. Indeed, the success of such an attempt would resolve the hidden trade wars, or otherwise, it would bring the trade wars into the light.

Disinformation whether intentionally or not distracts the health of all the markets. It is a threat for small firms, large ones, individual nations, and even for the global trade, because the health of decisions relies on the health of information. The main problem with the health of information is that (mostly) information providers are not directly responsible for their activities, or they are not faced with bad effects of their products. Setting of a guaranteed information system, where the information providers give guarantee about their products (inf) would be a solution. In such a system, information providers (accountants, auditors, analysts, and central bank or government spokesmen) would compensate the loss of information users because of false or misinformation.

In addition to this, financial reports usually include carefully selected round words which do not explicitly explain the financial situation of the organization. With these round words, information producers could camouflage or hide certain threats, risks or facts. A requirement, listing of explicit explanations of the risks, in financial reports would reduce such deficiencies. Furthermore, harmonization of accounting and financial reporting standards would reduce the risk of misunderstandings and misinterpretations.

Finally, unemployment may be one of the most serious problems which are very difficult to solve. Unemployment benefits and some temporary solutions eased the problem in the developed countries. However, unemployment is already a big and growing problem in the developing countries. Solutions like investing in infrastructure are temporary. When the project is completed, employees would be unemployed again. Other tactics like lower interest rate or undervalued currency policies could help to transfer certain amount of jobs to related countries which might cause unemployment in the previous countries, which means in total there is no change in unemployment.

\section{Risk of Second Wave?}

A few months after the global crises, majority of the academicians businessmen and statesmen declared that there would be V shaped (fast) recovery in the global economy, as if there was a consensus. Their main suggestion was that the global crisis occurred because of pessimistic psychology in the market place, in spite of strong economical basis. For them, global crisis was a routine correction which must be faced with, and the recovery should have to be as fast as crisis. But the time has proven that their suggestions did not come about.

On August 2009, Roubini again warned about the double-dip recession (W). He suggested that recovery was not soon, and even there was a recovery that would be (U shaped) in the long term. In this writing, he pointed out some critical issues like unemployment problem which has not been solved. He also criticized the liquid pumping policies by saying "this is a crisis of solvency, not just liquidity". Another issues mentioned in 
the article were "countries running current account deficits, financial system, weak profitability, and large fiscal deficits”.

In addition to these issues, it is suggested that lack of positive investment climate, Negligence of the basic rules (especially low interest rates), purposely weakened currencies, and lack of healthy financial information still remain as potential risk factors that could be reasons for the second wave of global crises.

\section{Conclusions and Suggestions}

In this study, it tries to analyze the risks and potential threats for the second wave of global crisis and criticize the policies driven for them. It is believed that potential risk factors which caused the crisis are not diminished and they stay as a threat for the global economy and trade. Deteriorated trade balance between China and other nations, specifically USA, has not been balanced, which has caused and is still causing budgets deficits. Budget deficit are considered as a reason for crisis, in contradiction to this budget, deficits are considered as a solution for crisis. Budget deficits are tried to be solved by undervalued currency policies by which completely or partially ignoring basic rules (PPP fisher effect theory etc.). Negligence of basic rules in international currency markets reduces the confidence to currencies, especially reserve currency US dollars, but the problems with that are: there is no substitute reserve currency for dollars and there is a need for reserve currency to be used for trading and savings. Undervalued currency policy is supported by zero base interest rate policies which distract the nature of the investment climate and trade: on one side, there is too much liquidation that cannot find any investment opportunity; on the other side, there is a short of liquidation. As a result of these policies, gold prices go up to record levels and are expected to go further, if there is no radical change in these policies.

Cheap Chinese labor force critically attracts the investing society on the behalf of China, against to other nations, which is causing the unemployment problem that is reducing the purchasing power of the workers in exporting countries. Unemployment could be serious in the near future, because existing solutions for it are temporal, assuming that the crisis will end by itself and everything will be fine afterwards. Besides, unemployment could create additional social problems in the nations, if it is not solved in time.

Trade surplus in China, the value of Yuan and cheap Chinese labor force could create serious disputes between China and other nations, specifically USA in the future.

The health of information became a serious problem after the accounting scandals in the US. Several regulations, including Act of SOX, could not ensure the health of financial information, for instance, dependent and independent bodies failed to warn the collapse of Lehman Brothers. Indeed, there is no serious unanimous effort to regulate and harmonize the accounting profession rules.

Furthermore, financial ammunitions (low interest rates, undervalued currencies, pumping liquidation etc.) are widely used by the nation. In the case of second wave, these financial weapons may not work because the markets might have immunity against to them.

\section{References}

Allen, F., \& Gale, D. (2000, January). Bubbles and Crises. The Economic Journal, 110(460), 236-255.

Arthur, T. (2000). Is the stock exchange a casino? Economic Affair, 20(4), 42-45.

Claessens, S., Kose, M., \& Terrones, M. (2008). What happens during recessions, crunches and busts? IMF Working Paper, 08/274, Washington, D.C.. 
Dreher, A., Herz, B., \& Karb, V. (2006). Is there a causal link between currency and debt crises? International Journal of Finance and Economics, 11, 305-325.

Eichengreen, B., \& Rose, A. (2001). Staying afloat when the wind shifts: External factors and emerging market banking crises. In G. A. Calyo, M. Obstfeld, \& T. Dornbusch (Eds.), Money, Capital Mobility, and Trade: Essays in Honor of Robert A. Mundell. Cambridge, M.A.: The MIT Press.

Grossman, S. J., \& Stiglitz, J. E. (1980). On the impossibility of informationally efficient markets, American Economic Review, 70(3), 393-408.

Kaminsky, G. L., \& Reinhart, C. M. (1999, July). The twin crises: The causes of banking and balance-of-payments problems. The American Economic Review, 89(3), 473-500.

Mihm, S. (2008, August 15). Dr. Doom. The New York Times. Retrieved from http://www.nytimes.com/2008/08/17/magazine/17pessimist-t.html?pagewanted=all

Minsky, H. (1992). The financial instability hypothesis. Working Paper 74. Annandale-On-Hudson. N.Y.: The Levy Economics Institute of Bard College.

Mishkin, F. S. (1991). Asymmetric information and financial crises: A historical perspective. In R. G. Hubbard (Ed.), Financial Markets and Financial Crises. Chicago: The University of Chicago Press.

Patricia, J. A. (2009). Global financial crisis: The challenge to accounting research. Accounting, Organizations and Society, 34, 803-809.

Reinhart, C. M., \& Rogoff, K. S. (2008). Is the 2007 us sub-prime financial crisis so different? An international historical comparison. American Economic Review, 98, 339-344.

Roubini, N. (2009). The risk of a double-dip recession is rising, Financial Times. Retrieved August 23, 2009, from http://www.Ft.Com/Cms/S/0/90227fdc-900d-11de-Bc59-00144feabdc0.Html?Nclick_Check=1

Shin, Y. S. (2005). Liquidity and twin crises. Economic Notes By Banca Monte, Dei Paschi Di Siena Spa, 3(34), $257-277$.

Yilmaz, C. (2009, October 16-17). Disinformation era in the information age: Is it the reason for global crises? 9th Global Conference on Business \& Economics 2009, UK: Cambridge University.

Yilmaz, C., Elitaş, C., \& Erkan, M. (2009). From accounting scandals to global crisis. Suleyman Demirel University the Journal of Faculty of Economics and Administrative Sciences, 14(2), 141-156. 